\title{
Reflexões sobre a prática extensionista com agentes comunitários de saúde: desafios e contradições da educação permanente
}

\author{
Michelly de Souza Faria, Eunice da Ferreira da Silva, Camila Ribeiro de Souza, Juliana Aparecida
} Caneschi, Fernanda Reis Souza, Beatriz Santana Caçador

\section{Resumo}

A prática profissional do Agente Comunitário de Saúde (ACS) tem como singularidade o paradoxo de ser membro da comunidade ao mesmo tempo em que pertence à equipe de saúde da família. Portanto, é complexo o fazer do ACS cuja prática é permeada por disputas paradigmáticas e indefinições acerca de sua natureza, escopo de suas ações e processo de formação. A respeito da formação do ACS, este profissional não recebe treinamento de forma sistematizada e, assim, desenvolve competências e habilidades com o tempo e a experiência. Das contradições inscritas na prática profissional do ACS e perante o cotidiano desafiador deste profissional, acredita-se que a Educação Permanente (EP) pode constituir-se como dispositivo de transformação de realidades ao proporcionar reflexões sobre sua prática e mobilizar intervenção nos serviços de saúde. Nesse sentido, o curso de Enfermagem da Universidade Federal de Viçosa desenvolve há dois anos um projeto de EP com ACS, experiência que tem sensibilizado os estudantes de enfermagem tanto na construção de habilidades e conhecimentos quanto na construção de significados ao seu processo de formação profissional e humana. Relatar a experiência de estudantes de enfermagem em projeto de EP para ACS, à luz das reflexões provocadas pela prática extensionista. Relato de experiência de atividades extensionistas do projeto "O Agente Comunitário de Saúde: (re)construindo práticas e saberes por meio da Educação Permanente" em Viçosa, Minas Gerais, de 2014 a 2016. As atividades ocorrem por oficinas educativas pautadas em metodologias participativas e problematização. A vivência proporciona reflexões acerca das contradições que permeiam a consolidação do SUS como sistema público e universal de saúde. Os estudantes tem a oportunidade de vivenciar de perto os dilemas da municipalização da saúde e as dificuldades estruturais da atenção básica no município. Ademais, a vivência no projeto permite maior aproximação com a realidade e criticidade na compreensão do processo de trabalho em saúde. Percebe-se que, embora existam avanços na estruturação dos serviços de saúde n município, a atenção primária saúde não é prioridade no conjunto das ações implementadas. Como na maior parte dos municípios interioranos do Brasil, os profissionais atuam em contextos precários, equipes incompletas e vínculos frágeis de trabalho. A atividade extensionista transita em uma arena delicada uma vez que, por natureza, é desafiada a intervir na realidade sem, no entanto, governabilidade política para direcionar mudanças no processo. A EP vincula-se a instituição de ensino que sofre cortes orçamentários e enfatiza atividades de pesquisa. Pensar a prática profissional constitui importante exercício de resistência ao contexto de crise Espera-se que a EP utilize seu potencial transformador da prática cotidiana de produção do cuidado em saúde e que o ACS, problematize e mobilize a capacidade de agir na realidade, possibilitando vislumbrar e construir práticas que se aproximem das prerrogativas jurídicas, éticas, ideológicas e legais do SUS.

Descritores: Agente comunitário de saúde; SUS; Saúde Pública. 